\title{
Role of Microtubules in Low Density Lipoprotein Processing by Cultured Cells
}

\author{
Richard E. Ostlund, JR., Barbara Pfleger, and Gustav Schonfeld, \\ Lipid Research Center and Metabolism Division, Departments of \\ Preventive Medicine and Medicine, Washington University School \\ of Medicine, St. Louis, Missouri 63110
}

A B S T RAC T The effect of the microtubule inhibitor colchicine on the metabolism of ${ }^{125}$ I-low density lipoprotein (LDL) by cultured human skin fibroblasts and aortic medial cells was studied in vitro. Colchicine did not alter the binding of LDL to cell surface receptors. However, the rate of LDL endocytosis was reduced to $58 \%$ of that expected. Despite diminished endocytosis, LDL was found to accumulate within the cells to $165 \%$ of that expected, whereas the release of LDL protein degradation products into the medium was reduced to $34 \%$ of control, findings consistent with a reduced rate of intracellular LDL breakdown. Colchicine did not alter cell content of the acid protease which degrades LDL, nor did $\left[{ }^{3} \mathrm{H}\right]$ colchicine accumulate in lysosomal fractions. However, colchicine did alter the intracellular distribution of both fibroblast lysosomes and endosomes. After colchicine, lysosomes tended to accumulate in the perinuclear region, whereas endosomes were found at the cell periphery. These findings are consistent with the hypothesis that ingested LDL is less available to lysosomal enzymes in the presence of colchicine. The actions of colchicine appear to be a result of destruction of cell microtubules. Lumicolchicine, a mixture of colchicine isomers which (unlike the parent compound) does not bind to the subunit of microtubules, was without effect.

The uptake and degradation of LDL by cultured cells consists of both a receptor-specific component and nonspecific pinocytosis. Important differences must exist between these processes because even large amounts of LDL taken up and degraded by the nonspecific route fail to regulate key aspects of intracellular cholesterol metabolism. Colchicine selectively inhibited receptormediated LDL degradation. No effect was demonstrable on the nonspecific degradation of LDL by familial hypercholesterolemia fibroblasts grown in

This paper was presented in part at the 1978 National Meeting of the American Federation for Clinical Research.

Received for publication 27 March 1978 and in revised form 23 August 1978 . medium containing serum and added sterols. The degradation of bovine albumin by normal cells was also unaffected. Colchicine sensitivity appears to be a biochemical marker for the LDL receptor-specific metabolic pathway.

Cytochalasins inhibit crosslinking and polymerization of cell microfilaments (although other important cell effects also occur). Cytochalasin D reduced LDL degradation to $44 \%$ of that expected. This result and the actions of colchicine suggest that cytoskeletal components such as microtubules and possibly microfilaments facilitate normal LDL metabolism.

\section{INTRODUCTION}

Low density lipoprotein (LDL) ${ }^{1}$ uptake and processing by cultured skin fibroblasts include several steps (1). LDL binds to cell surface receptors and is internalized in small endocytic vesicles that fuse with lysosomes (2). LDL is then degraded into free cholesterol and apoprotein fragments and the latter are released into the medium. There is reason to believe that cell microtubules and microfilaments might be involved in these processes.

Microtubules are 25-nm-diam, hollow core structures composed principally of tubulin (3). They appear to be required for saltatory movement of fibroblast lysosomes (4) and may also regulate the fusion of lysosomes with endocytic vacuoles (6-8) and alter the mobility of plasma membrane receptors (9). Tubulin is the only major cell protein that specifically binds colchicine $(3,5)$. The binding of colchicine causes depolymerization of microtubules, making colchicine useful as a probe for microtubular function in cells. Endocytosis is inhibited by colchicine in several systems $(10,11)$.

Microfilaments are morphologically quite distinct from microtubules. Composed principally of actin, they are 5-8 $\mathrm{nm}$ in diameter and may occur either in long

\footnotetext{
${ }^{1}$ Abbreviations used in this paper: BSA, bovine serum
} albumin; LDL, low density lipoprotein. 
bundles or in reticular networks (12). Cytochalasins interfere with the filament crosslinking necessary to form cytoplasmic microfilament gels (13) and also disrupt microfilaments directly at high concentration (14). The cytochalasins have other effects, however, including inhibition of glucose transport (15). Microfilaments are thought to affect a variety of endocytic (10) and secretory processes (16).

Because the interaction of LDL with cells involves endocytosis, we have studied the influence of colchicine and cytochalasins on LDL metabolism in cultured human skin fibroblasts and in aortic medial cells. We found that receptor-specific degradation of LDL was inhibited by colchicine, whereas nonspecific LDL degradation was not affected. Cytochalasin D also inhibited LDL degradation. Thus, "cytoskeletal" structures may importantly affect LDL metabolism.

\section{METHODS}

Reagents. Colchicine, cytochalasins $\mathrm{B}$ and $\mathrm{D}$, chloroquine, crystallized bovine serum albumin (BSA), grade II sodium heparin, cholesterol, and acridine orange grade II were supplied by Sigma Chemical Co., St. Louis, Mo. 25OH-cholesterol was purchased from Research Plus Laboratories, Denville, N. J. Fetal bovine serum was purchased from Gibco, Inc., Grand Island, N. Y. $\left[{ }^{3} \mathrm{H}\right]$ Colchicine was purchased from Amersham Corp., Arlington Heights, Ill. Lumicolchicine was prepared by the method of Mizel and Wilson (17). $50 \mu \mathrm{M}$ colchicine in absolute ethanol was irradiated for $20 \mathrm{~h}$ in an open 1,000-ml glass beaker placed in a Baker VB-400 hood (Baker Co., Inc., Sanford, Maine) equipped with an overhead germicidal lamp. The ethanol was evaporated and residual colchicine was extracted into water three times. The dried lumicolchicine had a ratio of absorbances at 350/267 $\mathrm{nm}$ of 0.067 and a molar extinction coefficient at $267 \mathrm{~nm}$ in ethanol of 22,800 . Lumicolchicine did not inhibit the binding of $\left[{ }^{3} \mathrm{H}\right]$ colchicine to brain tubulin when added in 50-fold excess.

Lipoproteins. LDL of density 1.019-1.063 was prepared from normal donors, iodinated by the iodine monochloride technique to a specific activity of $228 \pm 21$ (SEM) cpm/ng and diluted with native LDL to give a specific activity of $\cong 100$ $\mathrm{cpm} / \mathrm{ng} \mathrm{LDL}$ protein (18). All LDL additions were made as microgram per milliliter of LDL protein determined by the method of Sata et al. (19). BSA was iodinated by the method of Hunter and Greenwood (20) and purified by chromatography over Sephadex G-100 (Pharmacia Fine Chemicals, Piscataway, N. J.).

Cells. Normal fibroblasts were derived from skin explants taken from a 3-mo-old male, a 33-yr-old male, and a 40-yrold female. All normal lines gave similar results. Skin fibroblasts were also obtained from three patients with homozygous familial hypercholesterolemia. One is a 2-yr-old male who was classified as LDL "receptor-defective" on the basis of an LDL-induced:25-hydroxycholesterol-induced $\left[{ }^{14} \mathrm{C}\right]$ oleate incorporation ratio of $0.05: 1$, determined by published methods (21). Cells from two LDL "receptor-negative" patients, a 12-yr-old female (GM 996) and a 13-yr-old female (GM 1915) were purchased from the Human Genetic Mutant Cell Repository, Camden, N. J. Aortic cells were derived from an explant of thoracic aortic media taken at autopsy from a $2 \frac{1}{2}$ mo-old male who died of bronchopneumonia (26). Cell culture was as previously described (18). Fibroblasts were seeded at
75,000 per 35-mm-diam culture dish (or an equivalent amount for 60-100-mm dishes) and grown in $2 \mathrm{ml}$ Eagle's Minimum Essential Medium (Gibco) containing $50 \mu \mathrm{g} / \mathrm{ml}$ streptomycin, $50 \mathrm{U} / \mathrm{ml}$ penicillin, $1.25 \mu \mathrm{g} / \mathrm{ml}$ amphotericin B (Fungizone, Squibb Corp., New York), and $15 \%$ fetal bovine serum. After $72 \mathrm{~h}$ the medium was replaced and the cells were grown for another $72 \mathrm{~h}$. The medium then was removed, the cells were washed with $1 \mathrm{ml}$ Puck's saline G (22), and $1 \mathrm{ml}$ Eagle's Medium containing antibiotics, and $2.5 \mathrm{mg} / \mathrm{ml}$ human lipoprotein-deficient serum (18) was added. The cells were incubated 24 or $48 \mathrm{~h}$ before beginning an experiment. Aortic medial cells were grown similarly but in Dulbecco-modified Eagle's medium (Gibco) containing antibiotics, $15 \%$ fetal bovine serum, $1 \mathrm{mM}$ sodium pyruvate, and $0.1 \mathrm{mM}$ nonessential amino acids.

Cell ${ }^{125}$ I-LDL accumulation and degradation (18). Cells were incubated at least $24 \mathrm{~h}$ in $5 \%$ lipoprotein-deficient human serum. The medium was removed and each $35-\mathrm{mm}$ dish received $1 \mathrm{ml}$ of fresh medium containing $5-500 \mu \mathrm{g} / \mathrm{ml}$ ${ }^{125} \mathrm{I}-\mathrm{LDL}$. The cells were incubated at $37^{\circ} \mathrm{C}$ for $1-17 \mathrm{~h}$ after which the experiment was terminated by removal of the medium and placement of the cells at $4^{\circ} \mathrm{C}$. The cells were washed four times with $50 \mathrm{mM}$ Tris- $\mathrm{Cl}, \mathrm{pH} 7.4$, in $0.15 \mathrm{M}$ $\mathrm{NaCl}$ containing $2 \mathrm{mg} / \mathrm{ml}$ bovine albumin, and then twice with the preceding buffer without albumin. The cells were then dissolved in $0.1 \mathrm{~N} \mathrm{NaOH}$ for determination of accumulated ${ }^{125} \mathrm{I}$-LDL. In some experiments the cell surface ${ }^{125}$ I-LDL was removed before dissolving the cells in $\mathrm{NaOH}$ by incubation for $1 \mathrm{~h}$ at $4^{\circ} \mathrm{C}$ with $1 \mathrm{ml}$ Puck's saline $\mathrm{G}$ containing $10 \mathrm{mg} / \mathrm{ml}$ heparin with $\mathrm{pH}$ corrected to 7.4 (23). The saline $\mathrm{G}$ heparin was then aspirated and both it and cells, dissolved in $0.1 \mathrm{~N}$ $\mathrm{NaOH}$, were counted separately. The noniodide ${ }^{125} \mathrm{I}-\mathrm{LDL}$ degradation products soluble in $10 \%$ trichloroacetic acid (TCA) were determined in the removed culture medium (18). $1 \mathrm{ml}$ medium was added to $0.25 \mathrm{ml} 50 \%$ TCA. After $30 \mathrm{~min}$ at $4^{\circ} \mathrm{C}$ the tubes were centrifuged at $1,000 \mathrm{~g}$ for $10 \mathrm{~min}$ and $1.0 \mathrm{ml}$ of the supernate was removed and treated with $10 \mu \mathrm{l}$ $40 \% \mathrm{KI}$ and $40 \mu \mathrm{l} 30 \% \mathrm{H}_{2} \mathrm{O}_{2}$ for $5 \mathrm{~min}$ at room temperature. $2 \mathrm{ml} \mathrm{CHCl}_{3}$ was added and the tubes were thoroughly vortexed after which $0.5 \mathrm{ml}$ of the aqueous phase was counted. Blank dishes containing culture medium and ${ }^{125}$ I-LDL, but no cells, were routinely employed. Noniodide TCA soluble counts observed in blank dishes were subtracted from those of experimental dishes unless otherwise stated. Cell protein was determined by the method of Lowry et al. (24). Statistical comparisons were performed by Student's $t$ test. Means \pm SE of the mean are presented.

${ }^{125}$ I-LDL degradation by cell sonicates (25). Five 100-mm dishes of normal fibroblasts were grown in the usual fashion including 24-h incubation in medium containing $2.5 \mathrm{mg} / \mathrm{ml}$ lipoprotein-deficient serum. The cells were washed and scraped into $15 \mathrm{ml} 50-\mathrm{mM}$ Tris- $\mathrm{Cl}, \mathrm{pH} 7.4$, containing $0.15 \mathrm{M}$ $\mathrm{NaCl}$. The cells were collected at $90 \mathrm{~g}$ for $3 \mathrm{~min}$, washed in 5 $\mathrm{ml}$ of the same buffer, suspended in $0.75 \mathrm{ml}$ water, and sonicated for $1.5 \mathrm{~min}$ on ice. Experiments were performed by incubating $20 \mu \mathrm{l}$ of cell sonicate with $10 \mu \mathrm{l}{ }^{125} \mathrm{I}-\mathrm{LDL}$ containing $\cong 100,000 \mathrm{cpm}$ (final concentration, $5 \mu \mathrm{g} / \mathrm{ml}$ ) in 100 $\mu l 0.1 \mathrm{M}$ sodium acetate, $\mathrm{pH} 4.0$, containing $5 \mathrm{mM}$ dithiothreitol and $1 \mathrm{mM}$ EDTA for $1 \mathrm{~h}$ at $37^{\circ} \mathrm{C} .{ }^{125} \mathrm{I}-\mathrm{LDL}$ degradation products were then determined as described above.

Estimation of microtubules. An assay for microtubules in tissue culture cells is presented in detail elsewhere (36). Fibroblasts were taken to a $37^{\circ} \mathrm{C}$ room and washed six times with $0.15 \mathrm{M} \mathrm{NaCl}$. A 100-mm dish of cells was washed once (with $1 \mathrm{ml}$ ) and homogenized in $0.3 \mathrm{ml}$ microtubule stabilization buffer consisting of $10 \mathrm{mM}$ sodium phosphate ( $\mathrm{pH} 6.95$ ), $0.5 \mathrm{mM} \mathrm{MgCl}_{2}, 0.5 \mathrm{mM}$ guanosine 5'-triphosphate, $0.5 \mathrm{mM}$ EGTA, 50\% glycerol, and 5\% dimethylsulfoxide, and placed 
at $4^{\circ} \mathrm{C}$. Microtubules were separated from free tubulin by sedimentation of the former at $130,000 \mathrm{~g}$ for $10 \mathrm{~min}$ in a Beckman Airfuge (Beckman Instruments, Inc., Fullerton, Calif.). The microtubule-containing pellet was rehomogenized in 0.3 $\mathrm{ml}$ depolymerization buffer consisting of $0.25 \mathrm{M}$ sucrose, $0.5 \mathrm{mM}$ GTP, and $10 \mathrm{mM}$ sodium phosphate, $\mathrm{pH} 6.95$. After incubation at $4^{\circ} \mathrm{C}$ for $1 \mathrm{~h}$, the solution containing depolymerized microtubule subunits was clarified by centrifugation at $130,000 \mathrm{~g}$ for $10 \mathrm{~min}$. Colchicine binding activity of the supernate was determined by incubation at $37^{\circ} \mathrm{C}$ for $1 \mathrm{~h}$ with $1 \mu \mathrm{M}\left[{ }^{3} \mathrm{H}\right]$ colchicine. The binding of $\left[{ }^{3} \mathrm{H}\right]$ colchicine to microtubule protein fractions under these conditions is proportional to the amount of tubulin present. Microtubules in the absence of colchicine treatment contained $36 \pm 2 \%$ of the total cell tubulin.

\section{RESULTS}

Colchicine and LDL degradation. ${ }^{125} \mathrm{I}-\mathrm{LDL}$ metabolism was studied in human skin fibroblasts that
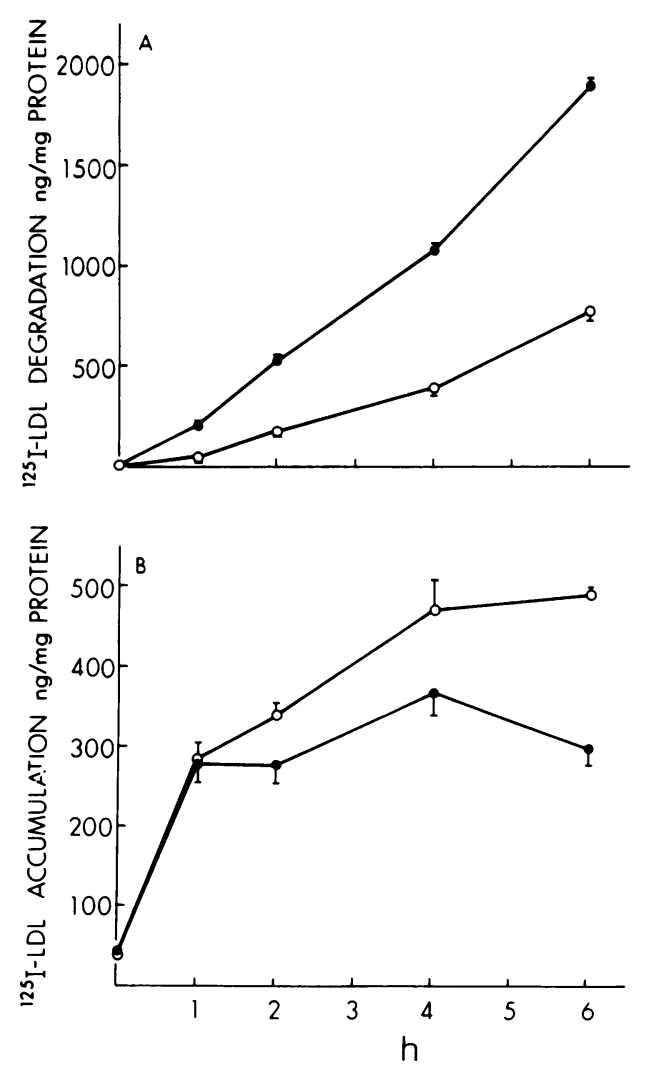

FIGURE 1 Effect of colchicine on ${ }^{125}$ I-LDL degradation and accumulation. Triplicate dishes of normal fibroblasts were prepared for LDL binding with a 24 -h incubation in lipoprotein-deficient serum (Methods). Some dishes received colchicine in a small volume of water sufficient to achieve a final concentration of $10 \mu \mathrm{M} 2 \mathrm{~h}$ before the experiment began. At zero time the medium was removed and replaced with fresh medium containing $10 \mu \mathrm{g} / \mathrm{ml}^{125} \mathrm{I}-\mathrm{LDL}$ either with or without $10 \mu \mathrm{M}$ colchicine. The cells were incubated for varying times at $37^{\circ} \mathrm{C}$. ${ }^{125} \mathrm{I}-\mathrm{LDL}$ degradation (panel $\mathrm{A}$ ) and accumulation (panel B) are presented; 9 , control; $\bigcirc, 10 \mu \mathrm{M}$ colchicine. Bars indicate SEM. had been previously treated with lipoprotein-deficient serum for $24 \mathrm{~h}$ to stimulate LDL uptake. ${ }^{125}$ I-LDL was added to control dishes and to dishes that had been preincubated for $2 \mathrm{~h}$ with $10 \mu \mathrm{M}$ colchicine. Cellular degradation and accumulation of ${ }^{125}$ I-LDL were then observed in the presence and absence of colchicine for up to $6 \mathrm{~h}$ (Fig. 1). Colchicine significantly reduced ${ }^{125} \mathrm{I}-\mathrm{LDL}$ degradation at all time points, the average reduction being to $33.9 \pm 3.8 \%$ of the control value (Fig. $1 \mathrm{~A} ; P<0.01$ ). The accumulation of ${ }^{125}$ I-LDL by colchicine-treated cells was increased after the $1 \mathrm{st} h$ and at $6 \mathrm{~h}$ was $165 \pm 2.1 \%$ of control (Fig. $1 \mathrm{~B} ; P<0.01$ ). In both control and colchicine-treated cells $>94 \%$ of the accumulated radioactivity was precipitable in $15 \%$ TCA at $0^{\circ} \mathrm{C}$.

Colchicine had similar effects in human aortic medial smooth muscle cells (Table I). At $10 \mu \mathrm{M}$ it reduced ${ }^{125}$ I-LDL degradation to $39 \%$ of control. A similar degree of inhibition of ${ }^{125}$ I-LDL degradation was noted in the presence of a 50-fold excess of unlabeled LDL. Accumulation of LDL was not significantly affected by colchicine.

A dose-response curve for the inhibition of ${ }^{125}$ I-LDL degradation in fibroblasts by colchicine is found in Fig. 2. Normal fibroblasts were preincubated for $2 \mathrm{~h}$ with colchicine and also received colchicine during a 2 -h incubation period with ${ }^{125}$ I-LDL. The lowest concentration of colchicine at which a significant reduction in LDL degradation occurred was $1 \mu \mathrm{M}$ where $61 \pm 5.0 \%$ of the expected release of LDL degradation products occurred. But the addition of up to $100 \mu \mathrm{M}$ colchicine caused no further decline in the release of degradation products. Lumicolchicine, a mixture of photochemical colchicine isomers which does not bind tubulin, had no significant effect upon ${ }^{125}$ I-LDL degra-

TABLE I

Effect of Colchicine on ${ }^{125}$ I-LDL Metabolism in Human Aortic Medial Cells.

\begin{tabular}{llc}
\hline & \multicolumn{2}{c}{${ }^{125}$ I-LDL } \\
\cline { 2 - 3 } & \multicolumn{1}{c}{ Degradation } & Accumulation \\
\hline & \multicolumn{2}{c}{$n g / m g$ protein/2 $h$} \\
Control & $39.0 \pm 1.6$ & $73.6 \pm 6.9$ \\
$10 \mu \mathrm{M}$ Colchicine & $15.2 \pm 1.6^{*}$ & $60.5 \pm 2.3$ \\
$500 \mu \mathrm{g} / \mathrm{ml}$ Unlabeled LDL & $16.1 \pm 1.4^{*}$ & $21.3 \pm 1.0^{*}$
\end{tabular}

Triplicate $35-\mathrm{mm}$ dishes were plated with 100,000 cells, grown as described in Methods, and prepared with lipoprotein-deficient serum. Colchicine-treated dishes received the drug during a 2 -h initial incubation period. At time zero, the medium was replaced with fresh medium containing $10 \mu \mathrm{g} / \mathrm{ml}{ }^{125} \mathrm{I}-\mathrm{LDL}$ and either colchicine, unlabeled LDL, or no addition, and the cells were incubated $2 \mathrm{~h}$ at $37^{\circ} \mathrm{C}$.

$* P<0.01$ compared to control. 
dation at concentrations from $0.01 \mu \mathrm{M}$ to $100 \mu \mathrm{M}$ (Fig. 2).

The effect of colchicine on fibroblast microtubule content was also studied (Fig. 2). Microtubules were reduced to $25 \%$ of expected levels by $0.1 \mu \mathrm{M}$ colchicine and to $4 \%$ by $1 \mu \mathrm{M}$ colchicine. Significant effects of colchicine on ${ }^{125}$ I-LDL degradation were noted at $1 \mu \mathrm{M}$ and greater concentrations. Thus, the degradation of ${ }^{125}$ I-LDL was reduced only in the absence of significant numbers of microtubules. However, a significant proportion of ${ }^{125}$ I-LDL was degraded even in the absence of detectable microtubules at $10 \mu \mathrm{M}$ colchicine (Fig. 1).

Effect of colchicine on nonspecific degradation. Fibroblasts from a normal subject and from patients with "receptor-defective" and "receptor-negative" hypercholesterolemia were tested for degradation of ${ }^{125} \mathrm{I}-\mathrm{LDL}$ in a single assay (Fig. 3). Colchicine treatment $(10 \mu \mathrm{M})$ reduced ${ }^{125}$ I-LDL degradation to $45 \%$ of that expected in normal cells, to $68 \%$ of that expected in LDL "receptor-defective" cells, and had no effect on "receptor-negative" cells. Because little LDL was degraded by cells deficient in receptors during a 2-h period, other experiments were performed (Table II). Colchicine reduced ${ }^{125}$ I-LDL degradation to $52 \%$ of control during a 6-h incubation using normal fibroblasts in which LDL receptors had been induced by preincubation for 24-h in lipoprotein-deficient serum.

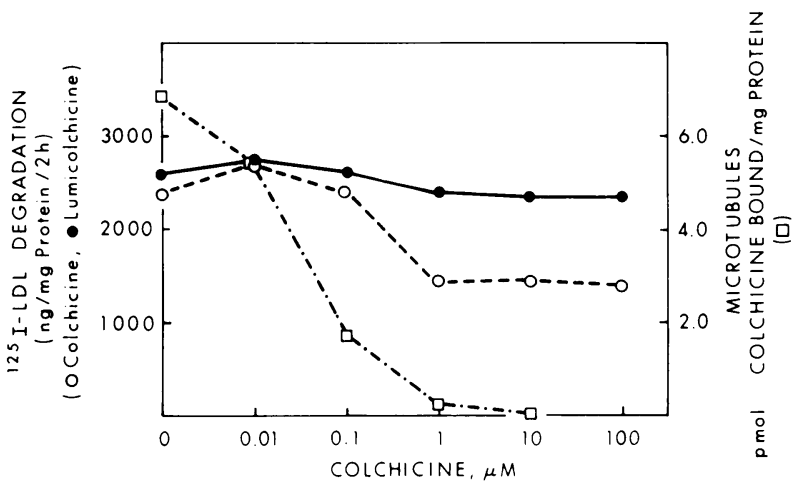

FIGURE 2 Effect of colchicine on microtubules and ${ }^{125}$ I-LDL degradation. Dishes used for the evaluation of ${ }^{125}$ I-LDL degradation were pretreated for $2 \mathrm{~h}$ with concentrated stock solutions of aqueous colchicine or lumicolchicine in ethanol, whereas untreated dishes received either $0.2 \%$ water or $0.2 \%$ ethanol. At time zero the medium was replaced with fresh medium containing the same additives as well as $100 \mu \mathrm{g} / \mathrm{ml}$ ${ }^{125}$ I-LDL and the dishes were incubated for an additional $2 \mathrm{~h}$ before determination of ${ }^{125} \mathrm{I}-\mathrm{LDL}$ degradation. Dishes used for quantitation of microtubules (Methods) received colchicine or water for $3 \mathrm{~h}$ without a medium change. ${ }^{125} \mathrm{I}-\mathrm{LDL}$ degradation in the presence or absence of colchicine and cell microtubule content were not altered by the amount of ethanol employed. Apparent degradation of ${ }^{125}$ I-LDL in dishes without cells was not subtracted from the values plotted. Each point represents the mean of three dishes.

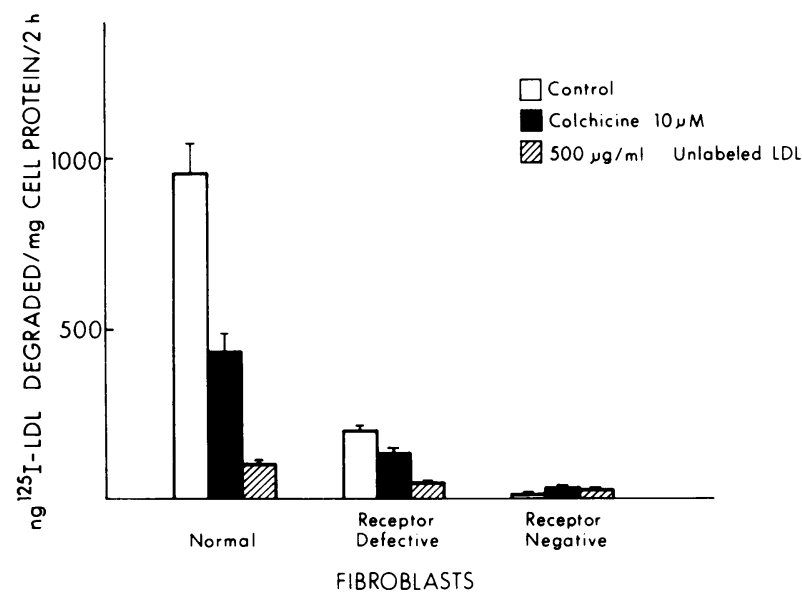

Figure 3 Effect of colchicine on ${ }^{125}$ I-LDL metabolism in fibroblasts of differing phenotype. Fibroblasts from a normal subject and from patients with "receptor-defective" and "receptor-negative" familial hypercholesterolemia were prepared for LDL binding by incubation $24 \mathrm{~h}$ in lipoproteindeficient serum. Colchicine was added in a small volume of water to certain dishes at $10 \mu \mathrm{M}$ final concentration $2 \mathrm{~h}$ before the experiment began. At zero time the medium was replaced with fresh medium containing $50 \mu \mathrm{g} / \mathrm{ml}{ }^{125} \mathrm{I}-\mathrm{LDL}$ and either $500 \mu \mathrm{g} / \mathrm{ml}$ unlabeled LDL, $10 \mu \mathrm{M}$ colchicine, or no addition. The dishes were incubated for $2 \mathrm{~h}$ at $37^{\circ} \mathrm{C} .{ }^{125} \mathrm{I}-\mathrm{LDL}$ degradation was assessed as described in the Methods section. Results are mean \pm 1 SEM.

Colchicine had no significant effect on ${ }^{125}$ I-LDL degradation in normal fibroblasts in which receptors had been suppressed by incubation in fetal bovine serum as well as cholesterol and 25-OH-cholesterol. In these experiments the concentration of ${ }^{125} \mathrm{I}-\mathrm{LDL}$ was raised to $500 \mu \mathrm{g} / \mathrm{ml}$ to increase the relative amount of nonspecific LDL degradation. LDL receptor-negative cells were also prepared by incubation in fetal bovine serum and added sterols. No effect of colchicine on ${ }^{125} \mathrm{I}-\mathrm{LDL}$ degradation was seen at either high $(250 \mu \mathrm{g} /$ $\mathrm{ml})$ or low $(5 \mu \mathrm{g} / \mathrm{ml})$ concentrations of ${ }^{125} \mathrm{I}-\mathrm{LDL}$. Thus, the effect of colchicine was observed only in cells having receptors for LDL.

The action of colchicine on the degradation of ${ }^{125} \mathrm{I}-$ BSA was investigated in a 17 -h incubation (Table II). Despite a $42 \%$ reduction in the degradation ${ }^{125}$ I-LDL in parallel dishes, no effect of colchicine was observed on ${ }^{125}$ I-BSA degradation.

Cytochalasin and LDL degradation. The effect of cytochalasins on LDL degradation is shown in Table III. Cytochalasin D at $10 \mu \mathrm{M}$ reduced ${ }^{125}$ I-LDL degradation to $44 \%$ of that expected. Similar to colchicine, the inhibition of degradation was not complete and even $100 \mu \mathrm{M}$ cytochalasin $\mathrm{D}$ was no more effective than $1 \mu \mathrm{M}$. Cytochalasin B had no effect on LDL degradation at $10 \mu \mathrm{M}$ (Table III).

Mechanism of colchicine action. A number of experiments was performed to localize the site of 
TABLE II

Effect of Colchicine on Nonspecific LDL Degradation

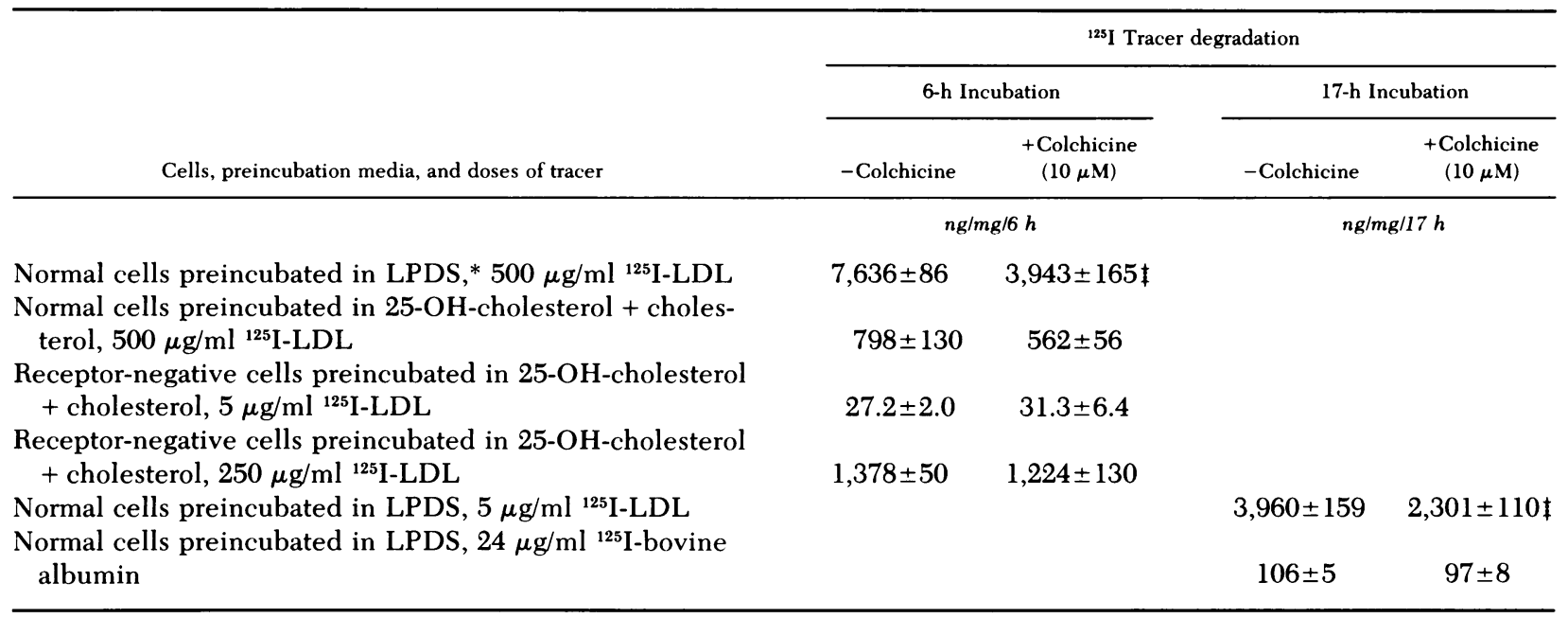

Three to five dishes per condition were preincubated for $24 \mathrm{~h}$ in either $5 \%$ lipoprotein-deficient serum (to induce LDL receptors) or in $15 \%$ fetal bovine serum containing $2 \mu \mathrm{g} / \mathrm{ml} 25-\mathrm{OH}$-cholesterol and $25 \mu \mathrm{g} / \mathrm{ml}$ cholesterol (to prevent induction of receptors). Dishes treated with colchicine received the drug in a small volume of water $2 \mathrm{~h}$ before as well as during the experiment. At time zero the medium of all dishes was replaced with Eagle's Medium $+5 \%$ lipoprotein-deficient serum containing tracer and the indicated drugs. Cells were incubated at $37^{\circ} \mathrm{C}$ for 6 or $17 \mathrm{~h}$. The amount of apparent tracer degradation in dishes containing no cells was subtracted from all entries.

* LPDS = Eagle's Medium + 5\% lipoprotein-deficient human serum.

$\ddagger P<0.001$ with respect to no colchicine.

colchicine action in fibroblasts. Receptor-bound ${ }^{125} \mathrm{I}-$ LDL that had not yet been internalized was eluted into a solution of heparin, which is known to bind LDL (23) (Table IV). Colchicine at $10 \mu \mathrm{M}$ had no significant effect upon heparin-releasable LDL.

The rate of LDL internalization was next considered. This was estimated as the sum of ${ }^{125}$ I-LDL accumulation and degradation in Fig. 1. At all time points, the rate of LDL uptake was significantly less in colchicinetreated cells, varying from $70 \%$ of that expected at $1 \mathrm{~h}$ to $58 \%$ at $6 \mathrm{~h}(P<0.05)$. Hence, colchicine decreased the rate of $\mathrm{LDL}$ endocytosis. But at the same time the accumulation of ${ }^{125} \mathrm{I}-\mathrm{LDL}$ in colchicine-treated cells was always equal to or greater than that of controls (Fig. $1)$. Because the heparin-elutable portion was unaffected by colchicine, this suggested that the rate of intracellular ${ }^{125} \mathrm{I}-\mathrm{LDL}$ processing must have been decreased to an even greater extent than the rate of endocytosis.

The possibility that colchicine inhibited the activity of enzyme(s) degrading LDL was tested. Colchicine inhibited ${ }^{125}$ I-LDL protein degradation in cell sonicates at very large concentrations (Table V). An inhibition of only $22 \%$ occurred at $100 \mu \mathrm{M}$ colchicine, whereas 1 $\mu \mathrm{M}$ was normally effective in our cell culture system (Fig. 2). However, it was possible that colchicine might have accumulated in lysosomes to sufficient concentration for inhibition of LDL degradation to occur during
TABLE III

Effect of Cytochalasins on ${ }^{125}$ I-LDL Degradation

${ }^{125}$ I-LDL degradation* ng/mg protein

2-h Preincubation

Control

$1,626 \pm 47$

Dimethylsulfoxide, 0.05 ( $\mathrm{vol} / \mathrm{vol})$

$1,504 \pm 64$

Cytochalasin D, $10 \mu \mathrm{M}$

$663 \pm 31$

Cytochalasin B, $10 \mu \mathrm{M}$

$1,736 \pm 52$

30-min Preincubation*

Control

Cytochalasin D, $0.1 \mu \mathrm{M}$

$2,380 \pm 138$

Cytochalasin D, $1 \mu \mathrm{M}$

$2,089 \pm 97$

Cytochalasin D, $10 \mu \mathrm{M}$

$1,327 \pm 102 \ddagger$

$1,263 \pm 30 \neq$

Cytochalasin D, $0.1 \mathrm{mM}$

Normal fibroblasts were prepared for LDL binding by incubation in lipoprotein-deficient serum. The triplicate dishes were preincubated with the appropriate drug in $0.05 \%$ dimethylsulfoxide (final concentration) for either $2 \mathrm{~h}$ or 30 min. At time zero the medium was replaced with fresh medium containing drug and $100 \mu \mathrm{g} / \mathrm{ml}{ }^{125} \mathrm{I}-\mathrm{LDL}$. The dishes were then incubated $2 \mathrm{~h}$ at $37^{\circ} \mathrm{C}$ and degradation of ${ }^{125} \mathrm{I}-\mathrm{LDL}$ was determined.

* Apparent degradation of ${ }^{125}$ I-LDL in dishes without cells was not subtracted from experimental results shown.

$\ddagger P<0.05$ compared to control or dimethylsulfoxide-treated dishes. 
TABLE IV

Heparin-Releasable ${ }^{125}$-LDL Binding

\begin{tabular}{|c|c|c|c|}
\hline & \multicolumn{3}{|c|}{${ }^{125}$ I-LDL } \\
\hline & \multicolumn{2}{|c|}{ Cell accumulation } & \multirow[b]{2}{*}{ Degradation } \\
\hline & $\begin{array}{l}\text { Heparin } \\
\text { elutable }\end{array}$ & $\begin{array}{l}\text { Heparin } \\
\text { resistant }\end{array}$ & \\
\hline & \multicolumn{3}{|c|}{ ng/mg protein } \\
\hline Control & $61.9 \pm 6.0$ & $506 \pm 32$ & $1,183 \pm 73$ \\
\hline $\begin{array}{l}+10 \mu \mathrm{M} \text { Colchicine } \\
+500 \mu \mathrm{g} / \mathrm{ml}\end{array}$ & $60.8 \pm 9.3$ & $850 \pm 145$ & $452 \pm 50^{*}$ \\
\hline Unlabeled LDL & $2.6 \pm 0.7^{*}$ & $25 \pm 6^{*}$ & $36 \pm 6^{*}$ \\
\hline
\end{tabular}

Fibroblasts prepared for LDL binding were incubated $2 \mathrm{~h}$ at $37^{\circ} \mathrm{C}$ with fresh medium containing $5 \mu \mathrm{g} / \mathrm{ml}{ }^{125}$ I-LDL after which binding and degradation assays were performed as described in Methods. Cells treated with colchicine received the drug for a 2 -h preincubation period as well as during the 2-h incubation.

${ }^{*} P<0.01$ compared to control.

the incubation of the intact cells. To test this possibility $\left[{ }^{3} \mathrm{H}\right]$ colchicine $(1 \mu \mathrm{M})$ was incubated with cells for $3 \mathrm{~h}$ and then the cells were washed and fractionated (Table VI). Over $97 \%$ of the colchicine counts were found in the $130,000 \mathrm{~g}$ supernate, and very little colchicine was found in any particulate fractions. Thus, concentration of colchicine in lysosomes did not occur, confirming predictions based on its $\mathrm{pK}$ of 12.5 (27). Therefore, direct inhibition of lysosomal enzymes could not have been a significant mechanism of colchicine action. Nor did colchicine affect the cell content of lysosomal LDL degrading enzymes. Fibroblasts were treated with $10 \mu \mathrm{M}$ colchicine or a similar small amount of water for $4 \mathrm{~h}$ and then sonicated in water to release lysosomal enzymes. ${ }^{125} \mathrm{I}-\mathrm{LDL}$ degradation in the sonicates was $4,171 \pm 330 \mathrm{ng} / \mathrm{mg}$ protein per $\mathrm{h}$ in con-

TABLE V

Effect of Colchicine on In Vitro Degradation of ${ }^{125}$ I-LDL

\begin{tabular}{ccc}
\hline \multirow{2}{*}{$\begin{array}{c}\text { Inhibitor } \\
\text { concentration }\end{array}$} & \multicolumn{2}{c}{ LDL degradation } \\
\cline { 2 - 3 } & Colchicine & Chloroquine \\
\hline$m M$ & \multicolumn{2}{c}{$\%$ of control \pm SEM } \\
0 & $100 \pm 2.3$ & \\
0.1 & $78.4 \pm 2.6$ & $78.3 \pm 7.3$ \\
1.0 & $49.5 \pm 7.7$ & $54.6 \pm 10.6$ \\
10 & $18.7 \pm 2.7$ & $18.5 \pm 1.3$ \\
70 & $4.1 \pm 1.5$ & $3.8 \pm 0.7$ \\
\hline
\end{tabular}

The degradation of ${ }^{125}$ I-LDL to TCA-soluble noniodide products by a fibroblast sonicate was determined at $\mathrm{pH} 4$ as described in Methods. Each number represents the mean of three determinations. Basal ${ }^{125}$ I-LDL degradation was $17.2-20.2 \mathrm{ng} / \mathrm{h}$
TABLE VI

Fractionation of Fibroblasts after Exposure to $\left[{ }^{3} \mathrm{H}\right]$ Colchicine

\begin{tabular}{lccc}
\hline & Fraction & Protein fraction & cpm \\
\hline & $c p m$ & $\mu g$ & $\mu g$ \\
Homogenate & 14,493 & 266 & 54.5 \\
500 g pellet & 119 & 58 & 2.1 \\
130,000 g pellet & 405 & 45 & 9.0 \\
130,000 g supernate & 14,114 & 97 & 146 \\
\hline
\end{tabular}

Normal fibroblasts were prepared as if for LDL binding by incubation in $5 \%$ lipoprotein-deficient serum for $24 \mathrm{~h}$. $\left[{ }^{3} \mathrm{H}\right]$ Colchicine at a final concentration of $1.0 \mu \mathrm{M}, 536,900$ $\mathrm{cpm} / \mathrm{ml}$, was added in a small volume and the cells were incubated at $37^{\circ} \mathrm{C}$ for $3 \mathrm{~h}$. They were then washed six times with $0.15 \mathrm{M} \mathrm{NaCl}$ and homogenized 100 strokes with a Teflonglass (DuPont Co., Wilmington, Del.) homogenizer in $0.3 \mathrm{ml}$ $0.25 \mathrm{M}$ sucrose containing $1 \mathrm{mM}$ EDTA $\mathrm{pH} 7.0$ and centrifuged at $500 \mathrm{~g}$ for $10 \mathrm{~min}$. The pellet was washed with the same buffer and recentrifuged. The supernate was centrifuged at $130,000 \mathrm{~g}$ (average) for $10 \mathrm{~min}$ in a Beckman Airfuge. The pellets were dissolved in $100 \mu 11 \mathrm{~N} \mathrm{NaOH}$ for counting. Numbers are the mean of two experiments.

trols and $4,103 \pm 228 \mathrm{ng} / \mathrm{mg}$ protein per $\mathrm{h}$ in colchicinetreated cells.

Chloroquine, too, inhibited LDL degradation in cell sonicates at high concentration (Table V). However, fibroblast lysosomes concentrate chloroquine to over $25 \mathrm{mM}$ under conditions similar to ours (28). The experiment of Table VII gave further evidence that the

TABLE VII

Effects of Colchicine and Chloroquine on ${ }^{125}$ I-LDL Metabolism

\begin{tabular}{lccc}
\hline \multicolumn{1}{c}{ Condition } & $\begin{array}{c}\text { 125I-LDL } \\
\text { accumulation }\end{array}$ & $\begin{array}{c}\text { 125I-LDL } \\
\text { degradation }\end{array}$ & $\begin{array}{c}\text { Degradation } \\
+ \text { accumulation }\end{array}$ \\
\hline & & $n g / m g$ protein/4 $h$ & \\
$\begin{array}{l}\text { Control } \\
\text { Colchicine, } \\
\quad 10 \mu \mathrm{M}\end{array}$ & $370 \pm 28$ & $1,087 \pm 50$ & $1,457 \pm 55$ \\
$\begin{array}{c}\text { Chloroquine, } \\
60 \mu \mathrm{M}\end{array}$ & $474 \pm 36$ & $398 \pm 36^{*}$ & $872 \pm 72^{*}$ \\
$\begin{array}{c}\text { Colchicine, } \\
10 \mu \mathrm{M}+\text { chlo- } \\
\text { roquine, } 60 \mu \mathrm{M}\end{array}$ & $402 \pm 23 \ddagger$ & $6.7 \pm 4.8 \ddagger$ & $410 \pm 24 \ddagger$ \\
\hline
\end{tabular}

Normal fibroblasts were grown and prepared for LDL binding as described in Methods. A small amount of colchicine stock was added to the medium of all colchicine-treated dishes $2 \mathrm{~h}$ before the experiment. At time zero the medium was aspirated and $10 \mu \mathrm{g} / \mathrm{ml}{ }^{125} \mathrm{I}-\mathrm{LDL}$ in fresh medium containing drugs or no addition was added. The cells were incubated at $37^{\circ} \mathrm{C}$ for $4 \mathrm{~h}$. Each number represents the mean of three or four plates.

${ }^{*} P<0.001$ compared to control.

$\ddagger P<0.05$ compared to chloroquine alone. 
mechanism of action of chloroquine differed from that of colchicine. Cells were incubated with chloroquine alone, colchicine alone, or both drugs. Chloroquine increased ${ }^{125}$ I-LDL accumulation in cells to $215 \%$ of that expected. Colchicine also increased ${ }^{125}$ I-LDL accumulation slightly (but in this case not significantly). But when the drugs were added simultaneously, antagonism resulted such that the increased LDL accumulation seen with chloroquine was significantly reduced to control levels. In contrast, the effect of the two drugs to lower ${ }^{125}$ I-LDL degradation was additive. This experiment suggested that colchicine increased fibroblast ${ }^{125}$ I-LDL accumulation by a different mechanism than chloroquine. The effect of colchicine occurred before lysosomal hydrolysis, the presumed site of chloroquine action.

Because colchicine has been reported to alter the intracellular spatial orientation of cell organelles (5), the distribution pattern of lysosomes and LDL-containing endosomes was studied with and without colchicine treatment (Fig. 4). Lysosomes visualized by supravital acridine orange staining $(37,38)$ were normally diffuse in cytoplasm, but tended to accumulate in the perinuclear region after colchicine (Fig. 4A, B). LDL-containing endosomes, also diffuse in the cytoplasm of untreated cells, assumed a distinctly peripheral pattern after colchicine treatment when visualized by indirect immunofluorescence (41) (Fig. 4C, D). Lumicolchicine $10 \mu \mathrm{M}$ had no effect on the distribution of either lysosomes or endosomes (results not shown).

\section{DISCUSSION}

Colchicine inhibited ${ }^{125}$ I-LDL degradation by cultured human fibroblasts and aortic medial cells to $35-55 \%$ of that expected. The effect appears to be a result of disaggregation of microtubules (Fig. 2). An amount of colchicine $(1 \mu \mathrm{M})$ that resulted in disaggregation of $96 \%$ of the microtubules also inhibited ${ }^{125}$ I-LDL degradation. However, there was no effect on LDL degradation at $0.1 \mu \mathrm{M}$ where microtubule disaggregation was $75 \%$ complete, suggesting that inhibition of ${ }^{125}$ I-LDL degradation required near total destruction of the microtubular cytoskeleton. Lumicolchicine (17), a mixture of colchicine isomers that does not bind to the subunit protein of microtubules, had no effect on ${ }^{125} \mathrm{I}$ LDL degradation.

The pathway of LDL degradation by tissue culture cells involves several discrete steps (1). LDL binds to a plasma membrane receptor which undergoes endocytosis in a vesicle. Fusion with lysosomes occurs after which LDL is hydrolyzed to free cholesterol and protein fragments in the secondary lysosome. We have studied the effect of colchicine on these processes.

The binding of ${ }^{125} \mathrm{I}-\mathrm{LDL}$ to its surface receptor was determined by heparin elution of cell-associated counts (23). Colchicine had no effect on receptor-bound LDL (Table IV). However, the rate of endocytosis, calculated as the sum of ${ }^{125}$ I-LDL cell accumulation and formation of ${ }^{125}$ I-protein degradation products, was reduced to $60 \%$ of that expected by colchicine (Table VII, Fig. 1).

Despite a reduced rate of endocytosis, colchicine increased cell accumulation of ${ }^{125}$ I-LDL (Fig. 1B). This required that colchicine reduce the effective rate of degradation of internalized ${ }^{125}$ I-LDL even more, either by reducing the fusion of endosomes with lysosomes or by directly inhibiting the activities or decreasing the amounts of the degrading enzymes.

There was no alteration in cell content of the lysosomal enzyme activity degrading LDL protein. Likewise, colchicine did not accumulate in lysosomes in sufficient amount to inhibit the degradative enzymes directly (Tables V and VI). The presence of adequate activities of degradative enzymes and of increased amounts of LDL in the cells suggested that colchicine produced a defect in endosome-lysosome fusion. This was supported by the altered distribution patterns of lysosomes stained with acridine orange $(5,37,38)$ and LDL endosomes visualized by immunofluorescence (Fig. 4). After colchicine treatment, lysosomes were found more prominently around the nucleus, whereas LDL endosomes were located more peripherally near the plasma membrane. Colchicine has been shown to inhibit endosome-lysosome fusion in several other cell types (6-8) and to stop the long saltatory movements of lysosomes in fibroblast-like cells (4).

Degradation of ${ }^{125}$ I-LDL by cultured fibroblasts can occur after LDL uptake either by specific cell receptors or by nonspecific pinocytosis (1). The LDL receptors greatly increase LDL uptake and degradation at low LDL concentrations $(5-10 \mu \mathrm{g} / \mathrm{ml})$, and this results in regulation of intracellular cholesterol metabolism as manifested by increased esterification of cholesterol, decreased hydroxymethylglutaryl coenzyme A reductase activity, and fewer LDL receptors $(1,31)$. However, at high LDL concentrations (e.g., $200 \mu \mathrm{g} / \mathrm{ml}$ ) the uptake and degradation of LDL by nonspecific pinocytosis may equal that mediated by receptors $(18,31)$. But when LDL is taken up and degraded even in large amount by the nonspecific route, there is no regulation of cholesterol metabolism (31). The biochemical basis of the difference between the specific and nonspecific "uptake pathways" is not known.

We have found that colchicine inhibited only specific receptor-mediated ${ }^{125}$ I-LDL degradation (Table II, Fig. 3). Colchicine had no effect on degradation of ${ }^{125}$ I-LDL taken up by nonspecific pinocytosis in receptor-negative cells treated with sterols, or in normal cells treated with sterols and assayed with a large concentration of ${ }^{125} \mathrm{I}-\mathrm{LDL}(500 \mu \mathrm{g} / \mathrm{ml})$ to increase the relative amount of nonspecific uptake (Table II). Colchicine had no effect 

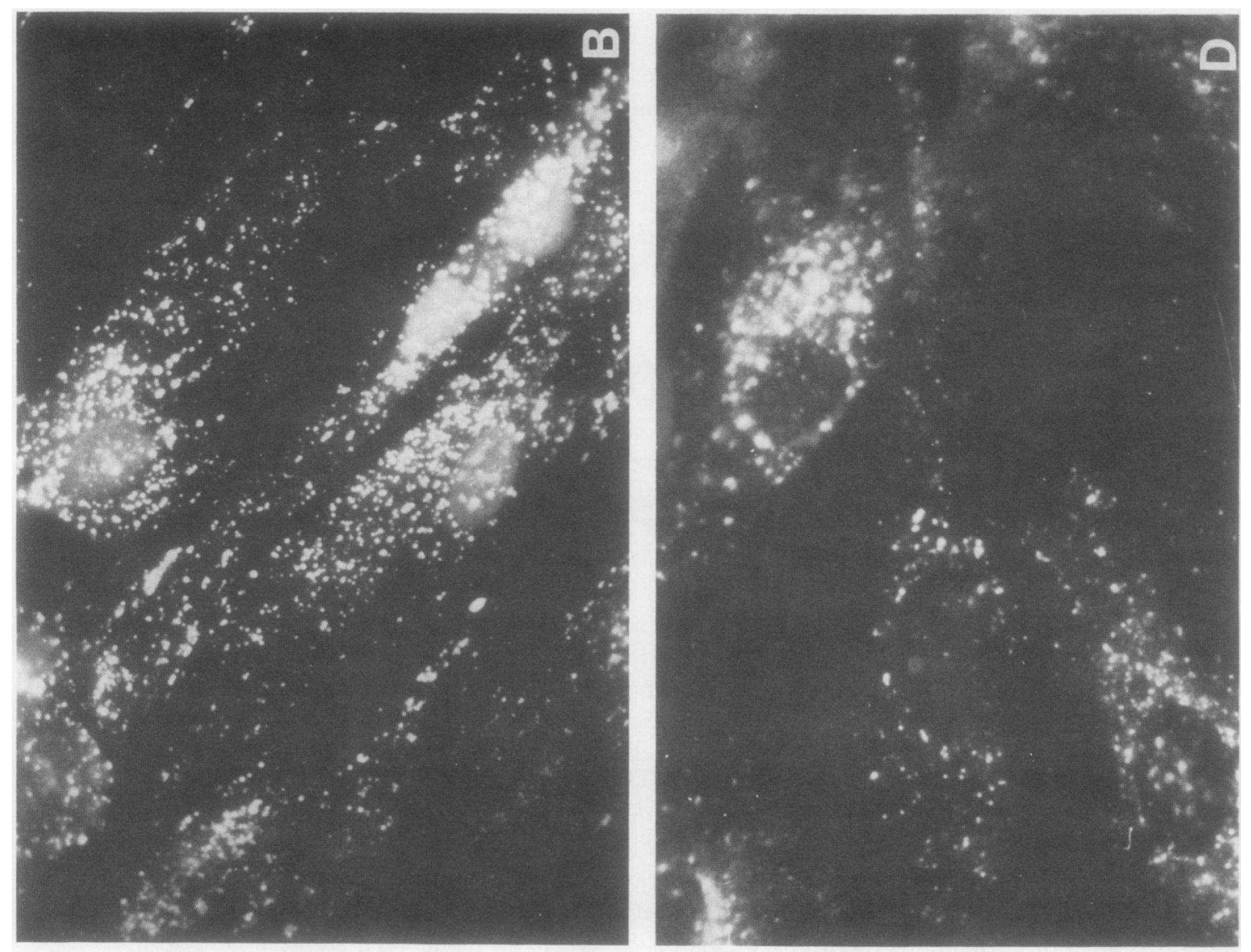

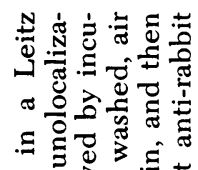

ช है

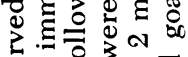

후워웡

잉.

ช.

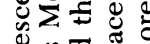

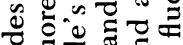

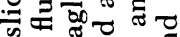

회되의

ชั

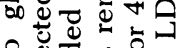

눙규워

ธ

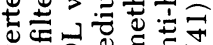

의

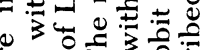

记范

하웡

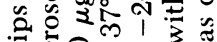

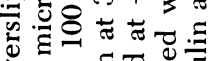

ठั

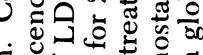

二

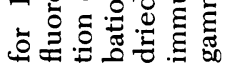
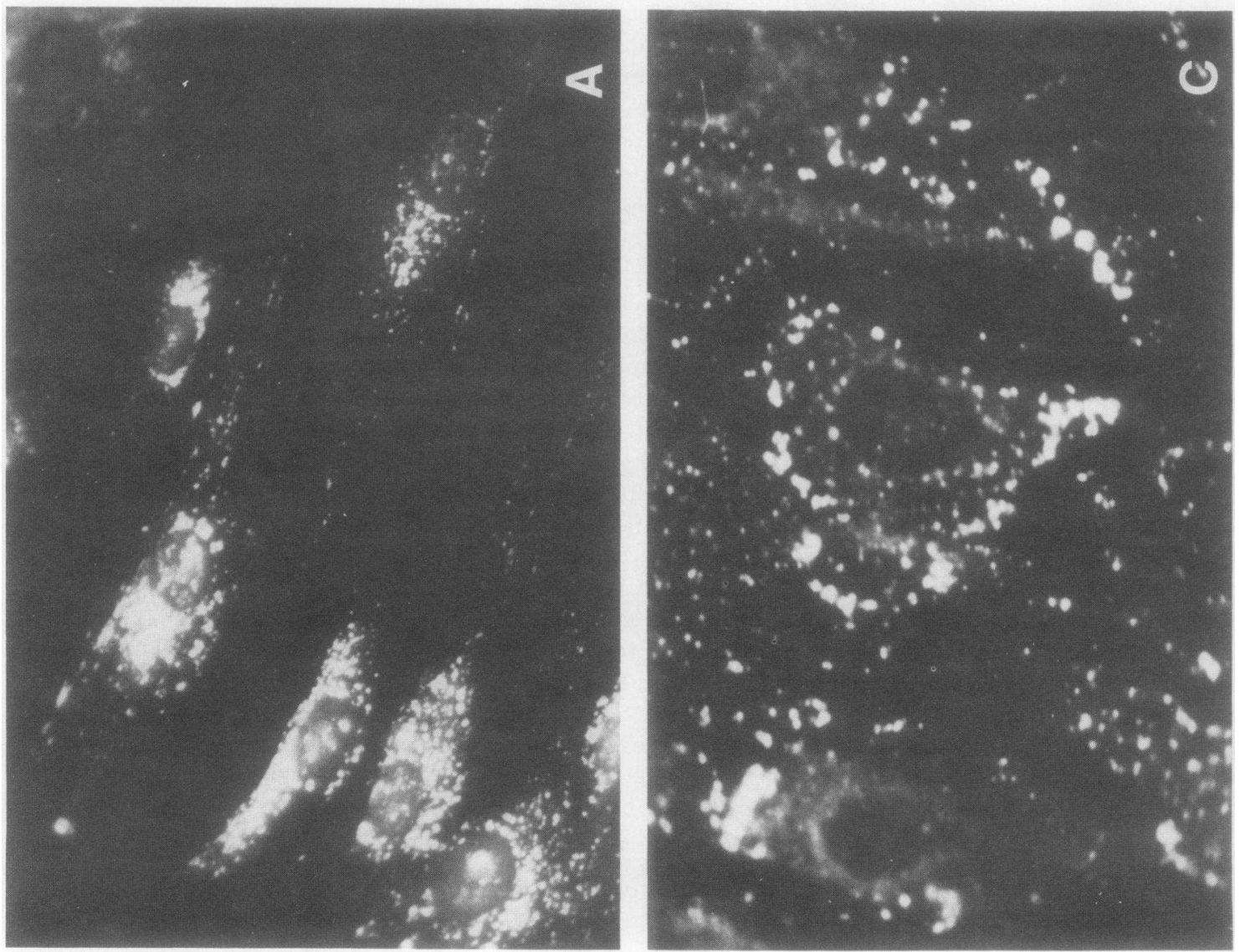

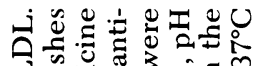

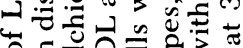

웡

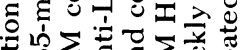

为

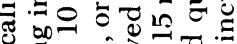

의 $=$ की

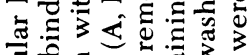

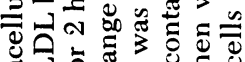

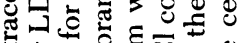

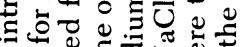

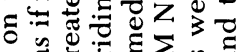

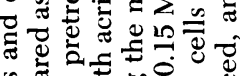

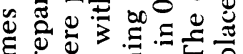

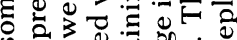

象的专

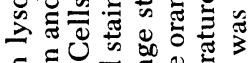

б

o

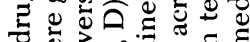

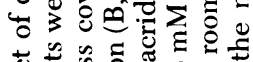

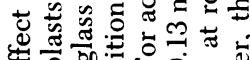

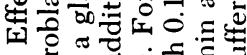

+

뚤

है 
on the degradation of ${ }^{125}$ I-BSA by normal cells under conditions where a significant reduction in ${ }^{125}$ I-LDL degradation was noted (Table II). Thus, colchicine sensitivity appears to be a biochemical marker for the receptor-specific pathway. This is consistent with published data demonstrating that uptake of small particles by pinocytosis is not sensitive to colchicine (32).

The selective inhibitory effect of colchicine on receptor-specific LDL degradation could have several explanations. Receptor-LDL binding may serve to organize microtubules to assist in the uptake and degradation of the bound material. The binding of concanavalin A to the plasma membrane has resulted in the apparent polymerization, or at least redistribution, of microtubules to greater density near the binding site $(34,35)$. Two types of endocytic vesicles have been identified in human skin fibroblasts (2); coated vesicles that contain the specific LDL receptors, and morphologically distinct, smaller, uncoated vesicles that do not contain LDL receptors but that are capable of nonspecific uptake of fluid from the cell exterior. It is possible that the preferential effect of colchicine on receptor-specific ${ }^{125}$ I-LDL degradation is because of an effect on the intracellular movement of the coated, but not the uncoated, vesicles. It is also possible that receptorspecific degradation of LDL occurs in specialized lysosomes and nonspecific degradation occurs in other lysosomes. For example, patients with ChediakHigashi syndrome demonstrate normal fusion of phosphatase-containing lysosomes with endocytic vesicles, but fusion of peroxidase and B-glucuronidasecontaining lysosomes is reduced (33). This suggests that fusion of some, but not all, lysosomes with endosomes may be facilitated by microtubules. The possibility that nonspecific degradation might occur in the cytoplasm must also be kept in mind (39), although published evidence indicates that nonspecific LDL degradation by familial hypercholesterolemia fibroblasts is highly chloroquine-sensitive and hence presumably occurs in lysosomes (40).

Cytochalasin D, but not cytochalasin B, also inhibited ${ }^{125}$ I-LDL degradation (Table III). Cytochalasins have several effects upon cells (13-15). However, the effect of cytochalasin D on LDL degradation could be a result of structural disorganization of actin-containing microfilaments, and the hypothesis that microfilaments are involved in cell LDL processing deserves further study.

We believe that agents active against microtubules and microfilaments may be useful probes for further defining the LDL receptor pathway.

\section{ACKNOWLEDGMENTS}

We thank Dr. Shirley Hajek for isolation of the aortic medial cells, Joyce T. Leung for determination of microtubules, and Lillie Beal for secretarial assistance.
This work was supported by Lipid Research Center National Institutes of Health contract NO1-HV-2-2916-L, U. S. Public Health Service grants HL15308, HL 15427, AM 20421, AM 20579, and a grant from the St. Louis Diabetic Children's Welfare Fund.

\section{REFERENCES}

1. Goldstein, J. L., and M. S. Brown. 1977. The low-density lipoprotein pathway and its relation to atherosclerosis. Annu. Rev. Biochem. 46: 897-930.

2. Anderson, R. G. W., M. S. Brown, and J. L. Goldstein. 1977. Role of coated endocytic vesicle in the uptake of receptor-bound low density lipoprotein in human fibroblasts. Cell. 10: 351-364.

3. Olmstead, J. B., and G. G. Borisy. 1973. Microtubules. Annu. Rev. Biochem. 42: 507-540.

4. Freed, J. J., and M. M. Lebowitz. 1970. The association of a class of saltatory movements with microtubules in cultured cells. J. Cell Biol. 45: 334-354.

5. Ostlund, R., and I. Pastan. 1975. Fibroblast tubulin. Biochemistry. 14: 4064-4068.

6. Malawista, S. E., and P. T. Bodel. 1967. The dissociation by colchicine of phagocytosis from increased oxygen consumption in human leukocytes. J. Clin. Invest. 46: 786-796.

7. Zurier, R. B., S. Hoffstein, and G. Weissman. 1973. Cytochalasin B: effect on lysosomal enzyme release from human leukocytes. Proc. Natl. Acad. Sci. U. S. A. 70: 844-848.

8. Oronsky, A., L. Ignarro, and R. Pepper. 1973. Release of cartilage mucopolysaccharide-degrading neutral protease from human leukocytes. J. Exp. Med. 138: 461-472.

9. Oliver, J. M., and R. B. Zurier. 1976. Correction of the characteristic abnormalities of microtubule function and granule morphology in Chediak-Higashi syndrome with cholinergic agonists. Studies in vitro in man and in vivo in the beige mouse. J. Clin. Invest. 57: 1239-1247.

10. Allison, A. C., and P. Davies. 1974. Interaction of membranes, microfilaments, and microtubules in endocytosis and exocytosis. In Advances in Cytopharmacology. B. Ceccarelli, F. Clementi, and J. Meldolesi, editors. Raven Press, New York. 2: 237-247.

11. Wolff, J., and J. A. Williams. 1973. The role of microtubules and microfilaments in thyroid secretion. Recent Prog. Horm. Res. 29: 229-285.

12. Ishikawa, H., R. Bischoff, and H. Holtzer. 1969. Formation of arrowhead complexes with heavy meromyosin in a variety of cell types. J. Cell Biol. 43: 312-328.

13. Hartwig, J. H., and T. P. Stossel. 1976. Interactions of actin, myosin, and an actin-binding protein of rabbit pulmonary macrophages. III. Effects of cytochalasin B. J. Cell Biol. 71: 295-303.

14. Spudich, J., and S. Lin. 1972. Cytochalasin B, its interaction with actin and actomyosin from muscle. Proc. Natl. Acad. Sci. U. S. A. 69: 442-446.

15. Mizel, S. B., and L. Wilson. 1972. Inhibition of the transport of several hexoses in mammalian cells by cytochalasin B. J. Biol. Chem. 247: 4102-4105.

16. Ostlund, R. E., Jr. 1977. Contractile proteins and pancreatic beta-cell secretion. Diabetes. 26: 245-254.

17. Mizel, S. B., and L. Wilson. 1972. Nucleoside transport in mammalian cells. Inhibition by colchicine. Biochemistry. 11: 2573-2578.

18. Goldstein, J. L., and M. S. Brown. 1974. Binding and degradation of low density lipoproteins by cultured human fibroblasts. J. Biol. Chem. 249: 5153-5162.

19. Sata, T., R. J. Havel, and A. L. Jones. 1972. Characterization of subfractions of triglyceride-rich lipoproteins separated by gel chromatography from blood plasma of 
normolipemic and hyperlipemic humans. J. Lipid Res. 13: 757-768.

20. Hunter, W. M., and F. C. Greenwood. 1962. Preparation of iodine-131 labelled human growth hormone of high specific activity. Nature (Lond.). 194: 495-496.

21. Goldstein, J. L., S. E. Dana, G. Y. Brunschede, and M. S. Brown. 1975. Genetic heterogeneity in familial hypercholesterolemia: evidence for two different mutations affecting functions of low-density lipoprotein receptor. Proc. Natl. Acad. Sci. U. S. A. 72: 1092-1096.

22. Puck, T. T., S. J. Cieciura, and A. Robinson. 1958. Genetics of somatic mammalian cells. III. Long-term cultivation of euploid cells from human and animal subjects. J. Exp. Med. 108: 945-956.

23. Goldstein, J. L., S. K. Basu, G. Y. Brunschede, and M. S. Brown. 1976. Release of low-density lipoprotein from its cell surface receptor by sulfated glycosaminoglycans. Cell. 7: 85-95.

24. Lowry, O. H., N. J. Rosebrough, A. L. Farr, and R. J. Randall. 1951. Protein measurement with the Folin phenol reagent. J. Biol. Chem. 193: 265-275.

25. Goldstein, J. L., G. Y. Brunschede, and M. S. Brown. 1975. Inhibition of the proteolytic degradation of low-density lipoprotein in human fibroblasts by chloroquine, concanavalin A, and Triton W. R. 1339. J. Biol. Chem. 250: 7854-7862.

26. Ross, R. 1971. The smooth muscle cell. II. Growth of smooth muscle in culture and formation of elastic fibers. J. Cell Biol. 50: 172-186.

27. DeDuve, C., T. DeBarsy, B. Poole. A. Trouet, P. Tulkens, and F. Van Hoof. 1974. Commentary lysosomotropic agents. Biochem. Pharmacol. 23: 2495-2531.

28. Wibo, M., and B. Poole. 1974. Protein degradation in cultured cells. II. The uptake of chloroquine by rat fibroblasts and the inhibition of cellular protein degradation and cathepsin $\mathrm{B}_{1}$. J. Cell Biol. 63: 430-440.

29. Pesanti, E. L., and S. G. Axline. 1975. Colchicine effects on lysosomal enzyme induction and intracellular degradation in the cultivated macrophage. J. Exp. Med. 141: 1030-1046.

30. Robbins, E., and N. K. Gonatas. 1964. Histochemical and ultrastructural studies on hela cell cultures exposed to spindle inhibitors with special reference to the interphase cell. J. Histochem. Cytochem. 12: 704-711.
31. Goldstein, J. L., and M. S. Brown. 1976. The LDL pathway in human fibroblasts: a receptor-mediated mechanism for the regulation of cholesterol metabolism. Curr. Top. Cell Regul. 11: 147-181.

32. Casley-Smith, J. R. 1969. Endocytosis: the different energy requirements for the uptake of particles by small and large vesicles into peritoneal macrophages. $J$. Microsc. (Oxf.). 90: 15-30.

33. Stossel, T. P., R. K. Root, and M. Vaughan. 1972. Phagocytosis in chronic granulomatosis disease and the ChediakHigashi syndrome. N. Engl. J. Med. 286: 120-123.

34. Hoffstein, S., R. Soberman, I. Goldstein, and G. Weissman. 1976. Concanavalin A induces microtubule assembly and specific granule discharge in human polymorphonuclear leukocytes. J. Cell Biol. 68: 781-787.

35. Albertini, D. F., and E. Anderson. 1977. Microtubule and microfilament rearrangements during capping of concanavalin A receptors on cultured ovarian granulosa cells. J. Cell Biol. 73: 111-127.

36. Pipeleers, D. G., M. A. Pipeleers-Marichal, P. Sherline, and D. M. Kipnis. 1977. A sensitive method for measuring polymerized and depolymerized forms of tubulin in tissues. J. Cell Biol. 74: 341-350.

37. Robbins, E., P. I. Marcus, and N. K. Gonatas. 1964. Dynamics of acridine orange-cell interaction. II. Dyeinduced ultrastructural changes in multivesicular bodies (acridine orange particles). J. Cell Biol. 21: 49-62.

38. Robbins, E., and P. I. Marcus. 1963. Dynamics of acridine orange-cell interaction. I. Interrelationships of acridine orange particles and cytoplasmic reddening. J. Cell Biol. 18: $237-250$.

39. Etlinger, J. D., and A. L. Goldberg. 1977. A soluble ATPdependent proteolytic system responsible for the degradation of abnormal proteins in reticulocytes. Proc. Natl. Acad. Sci. U. S. A. 74: 54-58.

40. Basu, S. K., J. L. Goldstein, R. G. W. Anderson, and M. S. Brown. 1976. Degradation of cationized low density lipoprotein and regulation of cholesterol metabolism in homozygous familial hypercholesterolemia fibroblasts. Proc. Natl. Acad. Sci. U. S. A. 73: 3178-3182.

41. Schonfeld, G., E. Bell, and D. H. Alpers. 1978. Intestinal apoproteins during fat absorption. J. Clin. Invest. 61: 1539-1550. 